\title{
Serbest eczane ekonomilerine etkili dışsal faktörlerin etki düzeyleri hakkındaki eczacı görüişleri
}

\author{
Bülent KIRAN, Elif Gizem KARACA, Duygu ÜLKAR
}

\begin{abstract}
Özet
Son ylllarda, Avrupa Birliği ve Dünya Sağlık Örgütü sağlık politikalarına uyum sağlamak ve ülkemizdeki sağlık hizmeti maliyetlerini düşürmek adına yeni yasal düzenlemeler gerçekleștirilmiştir. $\mathrm{Bu}$ düzenlemeler eczane ekonomilerini olumsuz yönde etkilemiştir. Eczacılar ise işletmelerini ayakta tutabilmek adına, çok sayıda dışsal etkenle mücadele etmek zorunda kalmıştır.

$\mathrm{Bu}$ çalışma, serbest eczane ekonomilerine etkili; benzer ürün satıcıları, medya, tüketici özellikleri, SGK ve Devlet politikaları gibi dışsal faktörlerin etki düzeyleri hakkında eczacı görüşlerini saptamak amaciyla, İzmir'de gönüllü 131 serbest eczaciya 30 sorudan oluşan bir anketin yüz yüze uygulanmasıyla gerçekleștirilmiştir. Veriler, SPSS 18 Paket Programı kullanılarak frekans, yüzde dağılım ve ki-kare testi ile değerlendirilmiştir. Araştırmaya katılan eczacıların, \%82,4'ünün en önemli ürün alıcısı Sosyal Güvenlik Kurumu ve reçeteli ilaç satışına etkili en önemli dışsal faktörün sağlık ve ilaç politikaları $(\% 96,2)$ olduğu
\end{abstract}

saptanmıștır. Ancak, eczacıların tamamına yakını (\%97) son yıllarda ilaçtan elde edilen kazanç azalınca ilaç dışı ürünlere yönelimin arttığını, bunun da eczane ekonomilerinin dışsal faktörlerden etkilenme düzeyini artırdığını düşünmektedir. Reklamlar $(\% 38,9)$ ve tüketici özellikleri $(\% 33,6)$ ise reçetesiz ürün satışına en çok etki eden başlıca dışsal faktörler olarak saptanmıştır.

Serbest eczane ekonomilerine etki eden dişsal faktörlerin etkisinin azaltılarak eczanelerin toplum sağlığına katkısının artırılabilmesi için araştırmaya katılan eczacıların \%88,5'inin devletin sağlık-ilaç politikalarında serbest eczane ekonomisini destekleyecek düzenlemelerin yapılmasını gerekli gördükleri, bunun için toplum sağlığına etkili ürünlerin sadece eczanede satılması başta olmak üzere tüketicilerin bilinçlendirilmesi vb. uygulamaların ivedilikle yaşama geçirilmesi gerektiğini düşündükleri saptanmıştır.

Anahtar Kelimeler: Eczacılık, Serbest Eczane, Eczane Yönetimi, Ekonomi
Bülent Kıran, Elif Gizem Karaca

Ege Üniversitesi, Eczacılık Fakültesi, Eczacılık İșletmeciliği Anabilim Dalı, İmir, Türkiye

Duygu Ülkar

T.C. Sağlık Bakanlı̆̆ı Balıkesir Bandırma Devlet Hastanesi, Balıkesir, Türkiye

Corresponding Author:

Bülent Kıran

e-mail:kiran.bulent@gmail.com

Submitted / Gönderilme: 13.03.2017 Revised / Düzeltme: 22.05.2017 Accepted / Kabul: $\quad 29.05 .2017$

How to cite this article: Kıran B, Karaca EG, Ülkar D. Serbest eczane ekonomilerine etkili dışsal faktörlerin etki düzeyleri hakkında eczacı görüşleri. Marmara Pharm J 2017; 21 (4): 1015-1023

\section{Giriş}

\section{Serbest Eczane Ekonomilerine Etkili Dış Faktörler}

AB (Avrupa Birliği) ve Dünya Sağlık Teşkilatı (DSÖ) sağlık politikalarına uyum amacıyla başlatılan "Sağlıkta Dönüşüm Projesi” kapsamında; ülkemizdeki ulusal ilaç, eczacılık, sağlık hizmetlerine dair yasal düzenlemeler hızla değişmektedir (1). Yeni yasal düzenlemeler, eczacılık meslek uygulamalarında önemli değişimlere ve sonuçlara yol açmaktadır. Sağlık hizmetlerinin özel sağlık kuruluşlarından, ilaçların da serbest eczanelerden satın alınmasına yönelik düzenlemelerle birlikte, eczane ekonomilerini doğrudan etkileyen bir dizi uygulamalar peşi sıra yürürlüğe girmiştir. Bunlardan biri, 2004 yılında yürürlüğe giren ve Avrupa Birliği (AB) ülkeleri arasından Sağlık Bakanlığı’nca belirlenen 5 ülkeden, fiyatı belirlenecek ürünün en ucuz olduğu 2 ülkedeki ürün 
fiyatları referans alınarak ilaç fiyatlarının belirlendiği ve ilaç harcamalarının bütçe yükünün azaltılmasına yönelik olan "referans fiyat" uygulamasını esas alan "İlaç Fiyat Kararnamesi"dir. (2, 3). Bu kararnameyle ilaç fiyatlarının 2004 ile 2009 yılları arasında $572 \mathrm{kez}$ düşürülmesi sonucu, eczanelerde önemli stok zararları oluşmuştur. Öte yandan, 2005 Mali Yılı Bütçe Uygulama Talimatı ile yürürlüğe giren ilaç giderlerini azaltmaya ve tasarrufa yönelik bir diğer uygulama ise, "Kamu Kurum Iskontosu (KKİ)" olarak nitelendirilen; "sözleşmeli eczaneler tarafından Sosyal Güvenlik Kurumuna (SGK) fatura edilen ilaçlarda, eczacı 1skontosuna ek olarak perakende satış fiyatı üzerinden belirlenen oranda indirim yapılmasına" yönelik düzenlemedir $(4,5)$. Ve yıllar içinde arttırılan KKİ ile eczane ekonomilerinde önemli kayıplar olmuştur. Ayrıca, 2009 yılında yürürlüğe giren ve 2009-2013 yılları arasında kamu ilaç harcamalarını 15-16 milyar TL'ye sabitleyerek sosyal güvenlik açıklarını azaltmaya yönelik "Global Bütçe Uygulaması" olarak tanımlanan bir diğer tasarruf amaçlı uygulama da ilaç piyasasında daralmaya neden olarak serbest eczane ekonomilerini olumsuz yönde etkilemiştir $(5,6)$.

Sağllk hizmetleri maliyetlerinin düşürülmesine ve tasarrufa yönelik olarak devlet tarafından yapılan tüm bu yasal düzenlemeler, süreç içerisinde eczacı kârlılığında ciddi düşüşlere ve eczane ekonomilerinde bozulmalara neden olmaya devam etmektedir (7). Buna karşın, son 10 yılda tüketici fiyat endeksi her yıl ortalama \%8,09 oranında artış göstermiş, bu durum ise serbest eczane işletme giderlerinin (kira, personel maaşları, elektrik, su vb. gibi) sürekli olarak artmasına neden olmuştur (8). Eczacılar bu koşullar altında eczane işletmelerinin yaşamını sürdürebilmesi için yeni stratejiler geliştirmeye çalışmaktadır. Bunlardan biri eczanelerdeki ürün çeşitliliğinin artırılmasına yönelik çalışmalardır. Ancak, ilaç dışı birçok sağlık ürününün eczane dışında da serbestçe satılabilmesi nedeniyle, eczacılar; aktar, dermakozmetik ve parfümeri, ttriyat satıcıları, gıda takviyesi satıcıları, tıbbi malzeme ve medikal satıcıları, süper marketler gibi serbest eczanelerin ürün yelpazesinde yer alan pek çok sağlık ürününün satıcısı konumunda olan ve bu konularda herhangi bir eğitimi olmayan diğer benzer ürün satıcıları ile haksız bir rekabet içine sürüklenmektedir (9).

Serbest eczane ekonomilerine olumsuz etki eden dişsal faktörler; eczanelerin yalnızca, benzer ürün satıcılarıyla yaşadıkları haksız rekabet sorunları ve hızla değişen sağlık, ilaç ve eczacilık politikaları sebebiyle bozulan eczane ekonomilerinden ibaret değildir. Ayrıca, nüfusun giderek değişen yaş, cinsiyet, gelir dağılımı, eğitim düzeyi, ülke içi göçlerle birlikte, komşu ülkelerden savaş sebebiyle yaşanan ek göçlerle artan kentleşme vb. özellikler yansıra, günümüzde yaygın olarak kullanılan sosyal, yazıll, görsel medya ve internet ile ilaç ve sağlık bilgilerine ve ürünlerine kolaylıkla erişimin sağlanabilmesi, algı yönetimi yapan reklamların artması, toplumun ilaç ve sağlık ürünleri kullanma alışkanlıklarına, dolayısıyla da serbest eczane ekonomilerine ve uygulamalarına etki eden önemli faktörler olarak ortaya çıkmaktadır (10-13).

$\mathrm{Bu}$ nedenle, serbest eczane ekonomilerine etkili dişsal faktörlerin ve etki düzeylerinin belirlenmesi, eczane işletmelerinin ekonomik olarak yaşamını sürdürebilmesinde doğru stratejik yöntemlerin geliştirilebilmesi adına önem taşımaktadır.

\section{Gereç ve Yöntem}

Bu çalışmada, serbest eczane ekonomilerine etki eden dişsal faktörler olarak; aktarlar, dermakozmetik satıcıları, marketler, internet üzerinden satış yapan satıcılar, Tv programları, tüketicilerin özellikleri (gelir, eğitim), medya, reklamlar, eczanenin lokasyonu, sağlık ilaç ve eczacılık politikaları, SGK ve sağlık politikaları "dışsal faktör" olarak ele alınmıştır. Araştırma, bu faktörlerin, serbest eczane ekonomilerine etki düzeyleri hakkındaki eczacı görüşlerini saptamak amacıyla gerçekleştirilmiştir.

Araştırma, İzmir ili merkez ilçeleri sınırları içinde faaliyet gösteren eczanelerden rastgele örnekleme yöntemiyle seçilen ve çalışmaya katılmayı kabul eden 131 serbest eczane ile gerçekleştirilmiş, kesitsel ve tanımlayıcı nitelikte bir araştırmadır. Anketler, 27 Şubat- 2 Haziran 2015 tarihleri arasında, eczacılarla yüz yüze görüşme yapılarak gerçekleştirilmiştir.

Veri toplama aracı olarak, gerekli literatür taraması ve pilot çalışma ardından geliştirilen ve 30 sorudan oluşan anket formu kullanılmıştır. Elde edilen veriler SPSS 18 Paket Programı kullanılarak frekans, yüzde dağılım ve ki-kare testi ile değerlendirilmiştir.

\section{Bulgular ve Tartışma}

Anketimize katılan serbest eczacıların \%58'i kadın, \%41,2'si erkektir. Yaş ortalamaları 45,73 olan eczacıların, yaklaşık olarak dörtte üçü $(\% 74,8) 10$ yıldan uzun bir süredir serbest eczacılık yapmaktadır. Araştırmanın yürütüldüğü eczanelerin \%29,8'i hastane civarı, \%36,6'sı cadde üzeri, \%14,5'i ASM civarı lokasyonda yer alırken, \%14,5'i de semt eczanesi niteliğindedir (Tablo 1). 
Tablo 1. Eczacıların serbest eczacılıktaki hizmet yılı ve eczanelerinin lokasyonu

\begin{tabular}{|l|c|c|}
\hline Eczacı ve Eczane Özellikleri & $\mathbf{n}=\mathbf{1 3 1}$ & Yüzde (\%) \\
\hline Hizmet Yılı & & \\
1-10 yıl & 33 & 25,2 \\
11-20 yıl & 51 & 38,9 \\
21-30 yıl & 27 & 20,6 \\
30 yıl ve üzeri & 20 & 15,3 \\
Lokasyon & & \\
Çarşı/Cadde Üstü & 48 & 36,6 \\
Hastane Civarı & 39 & 29,8 \\
ASM Civarı & 19 & 14,5 \\
Sokak içi/Semt & 19 & 14,5 \\
Diğer & 5 & 3,8 \\
Belirlenemeyen & 1 & 0,8 \\
\hline
\end{tabular}

*ASM: Aile Sağlı̆̆ı Merkezi

Araştırmanın yürütüldüğü eczanelerin büyük çoğunluğunun $(\% 82,4)$ en önemli ürün alıcısının SGK olduğu, \%74,8'inde ağırlıklı olarak ilaç satışı gerçekleşirken, \%20,6'sında ise ilaç ve ilaç dışı ürünlerin satışlarının eşit düzeyde olduğu saptanmıştır. Bu doğrultuda eczacıların en önemli ürün alıcıları ile eczanede en çok satışı gerçekleştirilen ürün grupları arasındaki fark incelenmiş ve istatistiksel olarak anlamlı bulunmuştur. ( $\left.x^{2}=47,446 \mathrm{p}=0,0001\right)$. Eczanesinde en çok ilaç grubu ürünlerin satışını gerçekleştirdiğini belirten eczacılar $(\% 95,9)$ en önemli ürün alıcılarının SGK olduğunu vurgulamıştır. Ayrıca, eczane lokasyonları ile eczanede en çok satışı gerçekleştirilen ürün grupları arasındaki fark incelenmiş ve bu gruplar arasındaki fark istatistiksel olarak anlamlı bulunmuştur. $\left(\mathrm{x}^{2}=21,586 \mathrm{p}=0,04\right)$ Hastane karşısındaki eczanelerde $(\% 89,7)$ en çokilaç satışı gerçekleştiği belirlenmiştir. Öte yandan eczanelerin \%84,7'sinin en önemli gelir kaynağı reçeteli ilaç satışları iken, eczanelerin yaklaşık olarak yarısının ise ilaç dışı ürün satışlarından elde ettikleri toplam payın yıllık cirolarının \%20-50'sine tekabül ettiği belirlenmiştir (Tablo 2).

2007 yılında, Türk Eczacıları Birliği tarafından yürütülen bir çalışmada da eczacıların en önemli gelir kaynaklarının resmi kurumlarla yapılan anlaşmalar sonucunda elde edilen gelirler olduğu bildirilmektedir (14). Ancak yine aynı araştırmada, ilaç dışı ürünlerin birçok eczane açısından önemli bir gelir kalemi olmadığı eczanelerin yaklaşık olarak \%60’ında ilaç dışı ürünlerden elde edilen gelirin toplam cironun \%10'undan azını oluşturduğu saptanmıştır (14). 2007 yılındaki araştırmaya göre günümüzde, ilaç dışı ürünlerin satış gelirlerinin eczane cirolarındaki payının giderek artmakta olduğu anlaşılmaktadır. Bu durumun hızla değişen ilaç ve sağlık politikaları ve eczacı karlılığının azalması sonucu eczacıların gelirlerini arttırabilmek ve işletmelerini ayakta tutabilmek amacıyla uyguladıkları ilaç dışı sağlık ürünleri çeşitliliğini artırma stratejilerinden kaynaklandığ 1 düşünülmektedir.

Tablo 2. Eczane ekonomilerini etkileyen önemli faktörlerin dağılımı

\begin{tabular}{|l|c|c|}
\hline & n=131 & $\begin{array}{c}\text { Yüzde } \\
(\%)\end{array}$ \\
\hline Eczanelerin En Fazla Satış Yaptıkları Ürün & & \\
Gruplarına Göre Dağılımı & & \\
İlaç satışı & 98 & 74,8 \\
İlaç dışı ürün satışı & 6 & 4,6 \\
Her ikisi de eşit & 27 & 20,6 \\
Eczanelerin En Önemli Ürün Alıcıları & & \\
SGK & 108 & 82,4 \\
Elden satış & 20 & 15,3 \\
Diğer & 3 & 2,3 \\
Eczanelerin En Önemli Gelir Kaynakları & & \\
Reçeteli ilaç satışı gelirleri & 111 & 84,7 \\
Reçetesiz ilaç OTC satışı gelirleri & 8 & 6,1 \\
İlaç dışı ürünlerin satı̧ gelirleri (dermokozmetik, & 10 & 7,6 \\
1triyat vb.) & & \\
Medikal-tıbbi malzeme satışı gelirleri & 2 & 1,5 \\
İlaç Dışı Ürün Satışlarının Yıllık Cirodaki Yüzde & & \\
Dağılımı & & \\
$<\% 10$ & 23 & 17,6 \\
\%10-19 & 27 & 20,6 \\
\% 20-29 & 35 & 26,7 \\
\%30-50 & 30 & 22,9 \\
> \% 50 & 15 & 11,5 \\
Belirlenemeyen & 1 & 0,8 \\
\hline
\end{tabular}

*OTC: Over The Counter (Reçetesiz satılabilen ilaçlar)

Tablo 3. Reçetesiz ürün satışlarına etki eden dışsal faktörler

\begin{tabular}{|l|c|c|}
\hline Reçetesiz Ürün Satışlarına Etki Eden Dışsal & $\mathbf{n = 1 3 1}$ & $\begin{array}{c}\text { Yüzde } \\
(\%)\end{array}$ \\
Faktörler & & \\
Benzer Ürün Satıcıları & 10 & 7,6 \\
Medya & 15 & 11,5 \\
Reklamlar & 51 & 38,9 \\
Tüketici Özellikleri & 44 & 33,6 \\
Diğer & 8 & 6,1 \\
Belirlenemeyen & 3 & 2,3 \\
Medya Aracılığıyla Reçetesiz Ürün Reklamı & & \\
Yapılmasını Doğru Buluyor Musunuz? & & \\
Evet & 57 & 43,5 \\
Hayır & 74 & 56,5 \\
\hline
\end{tabular}


Reçetesiz ürün satışlarında en etkili dışsal faktörlerin; "reklamlar" $(\% 38,9)$, tüketici özellikleri $(\% 33,6)$, medya $(\% 11,5)$ olduğu saptanmıştır. Reçetesiz ürün satışlarına daha az düzeyde etkili faktörlerin ise "benzer ürün satıcıları (aktar, kozmetik satıcıları, market, internet)" (\%7,6) ve "diğer faktörler (tanıdık tavsiyesi, doktor tavsiyesi vb.)” (\%6,1) olduğu saptanmıştır. (Tablo 3)

2015 yllında, Slovakya’da tüketiciler üzerinde yürütülen bir çalışmada da katılımcıların yarısından fazlasının OTC ve gida takviyesi satın alırken medyada yer alan reklamlardan etkilendiği belirlenmiştir (15). 2011 yılında İstanbul'da gerçekleştirilen ve üniversite öğrencilerinin ilaç/tıbbi ürün kullanımına yönelik tutumlarının değerlendirildiği bir diğer çalışmada ise öğrencilerin reçetesiz ilaç/tıbbi ürün alırken reklamlardan etkilenme oranı \%11,4 olarak bulunmuştur (11). Literatür incelendiğinde, tüketicilerin alışveriş esnasında plansız satın alma davranışlarının oldukça yüksek olduğu gözlenmektedir (16-18). Reklam gibi teşvik edici faaliyetlerin kişilerin karar verme sürecini etkilediği ve insanları belirli mal veya hizmetleri satın almaya ikna etmede önemli bir araç olduğu bilinmektedir (19).

Ancak, araştırmaya katılan eczacıların yarısından fazlasının $(\% 56,5)$ medya aracilığıyla hastalara doğrudan reçetesiz ilaç ve tıbbi ürün reklamı yapılmasını doğru bulmadığı da belirlenmiştir. (Tablo 3) 2013 yılında Ankara'da yapılan bir çalışmada da benzer sonuçlar elde edilmiş, eczacıların $\% 57,1$ 'i direk tüketiciye reçetesiz ilaç reklamı yapılmasını doğru bulmadığını, \%63,4’ü de bu tarz reklamların bilinçsiz ilaç tüketimini artırabileceğini, önemli sağlık sorunlarına ve yaşam kayıplarına yol açabileceğini belirtmiştir (20). 2012 yılında Ohióda yapılan bir araştırmada ise eczacıların yarısından fazlasının direk tüketiciye yönelik OTC reklamlarının hastaları gereksiz ilaç alımına yönelttiğini ve hastaların reklamını daha fazla gördükleri ilaçları tercih etme eğiliminde olduklarını gözlemledikleri saptanmıştır (21). 2012 yılında İstanbul'da serbest eczacılar, ilaç firmasında çalşsan eczacılar ve hekimlerle gerçekleştirilen bir odak grup görüşmesinde ise katılımcıların çoğu direk tüketiciye yönelik ilaç reklamlarının hasta ve insan haklarına zarar verebileceğini savundukları belirlenmiştir (22).

Araştırmamızda reçetesiz ürün satışlarına etki eden en önemli ikinci dışsal faktörün "Tüketici Özellikleri” $(\% 33,6)$ olduğu saptanmıştır. Bilindiği gibi tüketici davranışlarını ve satın alma kararlarını etkileyen pek çok faktör bulunmaktadır. Bunlar; kültürel (alt kültür, sosyal sınıf), sosyal (aile, meslek, statü), kişisel (yaş, yaşam dönemleri, yaşam tarzı, ekonomik durum), psikolojik (ihtiyaçlar, güdüler, algılar tutumlar, değer yargıları) özellikler olarak sinıflandırılabilmektedir $(23,24)$.

Öte yandan, araştırmaya katılan eczacıların, eczane ekonomilerine etkili dışsal faktörlerden "medya, tv programları, internet ve tüketici davranışları" hakkındaki görüşlerinin dağılımı Tablo 4’te görülmektedir. Buna göre, eczacıların tamamıma yakını (\%97) ilaçtan kazanç azalmasına bağlı olarak eczanelerde kazancı daha fazla olan ilaç dışı ürünlere yönelimin artmasının sonucunda, dışsal faktörlerin serbest eczacılığa olan etkilerinin arttığını düşünmektedir. Ayrıca, eczacıların \%88,6'sı gibi önemli çoğunluğu TV

Tablo 4. Eczane ekonomilerine etkili dışsal faktörlerden "Medya, TV Programları, İnternet Ve Tüketici Davranışları" hakkındaki eczacı görüşlerinin dağılımı

\begin{tabular}{|c|c|c|c|c|c|c|}
\hline & 焉 & 离 & 节 & 咅 & 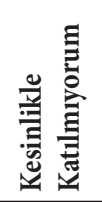 & 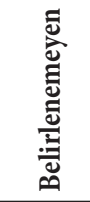 \\
\hline $\begin{array}{l}\text { İlaçtan kazanç azalınca, karı daha fazla olan ilaç dışı ürünlere } \\
\text { yönelimin artması sonucunda, dışsal faktörlerin serbest eczacılığa } \\
\text { olan etkilerinin arttığını düşünüyorum }\end{array}$ & $\begin{array}{c}96 \\
(\% 73,3)\end{array}$ & $\begin{array}{c}31 \\
(\% 23,7)\end{array}$ & $\begin{array}{c}4 \\
(\% 3)\end{array}$ & - & - & - \\
\hline $\begin{array}{l}\text { Medyanın tüketici/hasta davranışlarını kuvvetle etkilediğini } \\
\text { düşünüyorum }\end{array}$ & $\begin{array}{c}69 \\
(\% 52,7) \\
\end{array}$ & $\begin{array}{c}47 \\
(\% 35,9) \\
\end{array}$ & $\begin{array}{c}3 \\
(\% 2,3) \\
\end{array}$ & $\begin{array}{c}11 \\
(\% 8,4) \\
\end{array}$ & - & $\begin{array}{c}1 \\
(\% 0,8) \\
\end{array}$ \\
\hline $\begin{array}{l}\text { TV programları, medya ve marketlerdeki pazarlama faaliyetleri } \\
\text { ile tüketicilerde eczanede satılan ürün pahalıdır imajı yaratıldığını } \\
\text { düşünüyorum }\end{array}$ & $\begin{array}{c}41 \\
(\% 31,3) \\
\end{array}$ & $\begin{array}{c}46 \\
(\% 35,1) \\
\end{array}$ & $\begin{array}{c}8 \\
(\% 6,1) \\
\end{array}$ & $\begin{array}{c}27 \\
(\% 20,6)\end{array}$ & $\begin{array}{c}8 \\
(\% 6,1) \\
\end{array}$ & $\begin{array}{c}1 \\
(\% 0,8)\end{array}$ \\
\hline $\begin{array}{l}\text { İnternet üzerinden satılan ilaç ve ilaç dışı ürünlerin eczanemin } \\
\text { satışını etkilediğini düşünüyorum }\end{array}$ & $\begin{array}{c}70 \\
(\% 53,4) \\
\end{array}$ & $\begin{array}{c}46 \\
(\% 35,1) \\
\end{array}$ & $\begin{array}{c}3 \\
(\% 2,3) \\
\end{array}$ & $\begin{array}{c}8 \\
(\% 6,1) \\
\end{array}$ & $\begin{array}{c}2 \\
(\% 1,5) \\
\end{array}$ & $\begin{array}{c}2 \\
(\% 1,5) \\
\end{array}$ \\
\hline $\begin{array}{l}\text { İnternet yoluyla ilaç veya ilaç dışı ürün alınmasının tüketicinin gelir } \\
\text { ve eğitim düzeyiyle ilgili olduğunu düşünüyorum }\end{array}$ & $\begin{array}{c}34 \\
(\% 26)\end{array}$ & $\begin{array}{c}53 \\
(\% 40,5)\end{array}$ & $\begin{array}{c}5 \\
(\% 3,8)\end{array}$ & $\begin{array}{c}28 \\
(\% 21,4)\end{array}$ & $\begin{array}{c}10 \\
(\% 7,6)\end{array}$ & $\begin{array}{c}1 \\
(\% 0,8)\end{array}$ \\
\hline
\end{tabular}


programları ve medyanın tüketici davranışlarını etkilediğini ve $\% 66,4$ '̈u ise TV programları, medya ve marketlerdeki pazarlama faaliyetleri ile toplum üzerinde eczanede satılan ürünlerin pahalı olduğu imajı yaratıldığını düşünmektedir. Yine, eczacıların çoğu $(\% 88,5)$ internet üzerinden satılan ilaç ve ilaç dışı ürünlerin kendi eczanesinin satışını olumsuz etkilediğini düşünmektedir (Tablo 4). Nitekim, Konyada eczanelerin hizmet kalitesi ve hasta beklentileriyle ilgili yapılan bir araştırmada da halkın ilaç dışı ürünleri, ürün çeşitliliği, kampanya ve indirimler, ürün karşılaştırma olanağ 1 olması, mesai saatlerinin esnek olması, diğer alışverişleriyle birlikte AVM (Alışveriş Merkezi) içinden alım yapabilmeleri, eczanede satı̧ baskısıyla karşılaşmaları gibi sebeplerle, eczane dışından temin etmeyi seçtikleri gösterilmiştir (13).

Diğer taraftan, araştırmaya katılan eczacıların yaklaşık olarak yarısının $(\% 48,9)$ benzer ürün satışı yapan diğer satıcılarla rekabet etmeye çalıştığ 1 ve bu eczacıların $(\% 67,2)$ 'sının rekabet yöntemi olarak tüketicilere bizzat danışmanlık hizmeti sunarak eczanelerini tercih etmelerini sağladıkları saptanmıştır (Tablo 5). Ancak, reklam araçlarıyla rekabette eczacıların yasal açıdan benzer ürün satıcılarına göre dezavantajlı olduğu anlaşılmaktadır. Zira, benzer ürün satıcılarının sıklıkla başvurduğu bir satış fonksiyonu olan afiş ve reklam uygulamasının eczanelerde

Tablo 5. Eczacıların benzer ürün satıcılarıyla rekabet etme durumu

\begin{tabular}{|l|c|c|}
\hline & $\mathbf{n = 1 3 1}$ & $\begin{array}{c}\text { Yüzde } \\
(\%)\end{array}$ \\
\hline $\begin{array}{l}\text { Evet Benzer Ürün Satıcılarıyla Rekabet Etmeye } \\
\text { Çalışıorum }\end{array}$ & $\mathbf{n = 6 4}$ & $\mathbf{4 8 , 9}$ \\
$\begin{array}{l}\text { Tüketicilere bizzat danışmanlık yaparak eczanemi } \\
\text { tercih etmelerini sağlıorum }\end{array}$ & 43 & 67,2 \\
$\begin{array}{l}\text { Eczane içinde pazarlama-reklam ve tanıtıma ağırlık } \\
\text { veriyorum }\end{array}$ & 13 & 20,3 \\
Pazarlama yöntemleri kullanıyorum & 5 & 7,8 \\
Diğer & 3 & 4,7 \\
Hayır Benzer Ürün Satıcılarıyla Rekabet Etmeye & $\mathbf{n = 6 6}$ & $\mathbf{5 0 , 4}$ \\
Çalışmıyorum & 31 & 47 \\
Rekabete değer bulmuyorum & 14 & 21,2 \\
Rekabet edebileceğimi düşünmüyorum & 8 & 12,1 \\
Çevremde rekabet edebileceğim benzer ürün satıcısı & $\mathbf{n}$ & \\
yok & 5 & 7,6 \\
İlaç dışı ürün satışım yok & 2 & 3 \\
Belirlenemeyen & 6 & 9,1 \\
Diğer & $\mathbf{0 , 7}$ \\
Belirlenemeyen &
\end{tabular}

kullanımı, Eczacılar ve Eczaneler Hakkında Yönetmelik ve bu yönetmeliğin 50. Maddesine göre hazırlanan İyi Eczacılık Uygulamaları Kılavuzu'nda yer alan "Eczane vitrinlerine reklam asılamaz, promosyon amaçl ilaç satışı yapılamaz." ibaresi ile yasaklanmıştır (25). Bu durumda, gerek kozmetik ve dermakozmetikler, gerekse bitkisel preparatlar ve gıda takviyeleri konularında lisans eğitimi almış tek meslek grubu olan eczacilara, ilan ve reklam konusunda bu kadar sıkı yaptırımlar uygulanırken, bu konularda eğitimi olmayan benzer ürün satıcılarının, hiç denetlenmiyor oluşunun da eczaneler aleyhine haksız rekabet yaratan bir uygulama olduğu düşünülmektedir.

Diğer yandan, benzer ürün satıcıları başlığı altında incelediğimiz ve günümüzde pek çok sektör tarafından pazarlama aktivitelerinin vazgeçilmezi olan internetten yapılan satışlar da eczaneleri zor durumda bırakan bir başka etkendir (26). Son ylllardaki yeni yasal düzenlemelerle eczane eczaciları ve eczaneler adına internet sitesi ve sosyal medya hesabı açılması yasaklanmış, eczacıların internet veya başka herhangi bir elektronik ortamda satış yapamayacağ 1 belirtilmişken, eczacılıkla hiç ilgisi olmayan pek çok kişi eczanede satılan ve tedavi endikasyonu olan ürün gruplarının internet üzerinden satı̧̧ ve pazarlama faaliyetlerini gerçekleştirebilmektedir $(26,27)$. Araştırmamıza katılan eczacıların \%88,5’i de internet üzerinden satılan ilaç ve ilaç dışı ürünlerin eczanelerinin satışını etkilediğini düşünmektedir. (Tablo 4). Bu durumun gerek eczacilık mesleği, gerekse toplum sağlığı açısından tehlike arz ettiği düşünülmektedir. 2014 yılında, Avustralya'da yapılan bir çalışmada internet üzerinden satışı gerçekleştirilen 121 bitkisel ilacın 22'sinin ruhsatsız olduğu geri kalan 99 tanesinden 59'unun ise içerdiği etken madde miktar ve konsantrasyonlarının ruhsatında belirtilenle aynı oranda olmadığı görülmüştür (28). Ayrıca, Türk Eczacıları Birliği’nin 2016 yılında yaptığı bir basın açıklamasında da internetten temin edilen her 10 ilaçtan 8'inin sahte olduğu ve bu durumun insan sağlığını ve yaşamını tehdit ettiği belirtilmiştir (29). Bu bağlamda, Türk Eczacıları Birliği gerek internetten satın alınan sahte ilaçların kullanımına bağlı ölümleri, gerekse internet üzerinden ilaç satışının artışını engellemek adına internetten ilaç satışı yapan sitelere yönelik bir ihbar hattı oluşturmuştur (29). Bu ihbar hattının internet üzerinden ilaç satışını engellemek adına gerekli ancak yeterli bir uygulama olmadığı, bu konuda gerekli yasal düzenlemelerin kamu otoritesi tarafından yapılarak internet üzerinden ilaç satışı yapan sitelere yaptırımı ağır, caydırıcı cezalar uygulanması gerektiği düşünülmektedir. 
Tablo 6. Eczacıların reçeteli ilaç satışlarına etki eden dışsal faktörler hakkındaki görüşleri

\begin{tabular}{|l|c|c|}
\hline & $\mathbf{N}=\mathbf{1 3 1}$ & Yüzde (\%) \\
\hline Devlet Politikaları ve SGK Yaptırımları & 126 & 96,2 \\
\hline Tüketici Özellikleri & 3 & 2,3 \\
\hline Belirlenemeyen & 2 & 1,5 \\
\hline
\end{tabular}

Araştırmaya katılan eczacıların tamamına yakının (\%96,2), reçeteli ilaç satışlarına etki eden en önemli dişsal faktörün devlet politikaları (sağlık, ilaç ve eczacılık uygulamaları) ve SGK yaptırımları olduğunu düşündükleri anlaşılmıştır (Tablo 6). Eczaciların devlet politikaları ve SGK yaptırımlarından bu denli etkilenmelerinin temelinde en büyük gelir kaynaklarının reçeteli ilaçlar olması ve eczanelerin \%82,4'ünün en önemli ilaç alıcısının SGK olmasının etkili olduğu düşünülmektedir. Nitekim bazı araştırmalarda, SGK protokolünden kaynaklanan uygulamaların, eczane ekonomilerini ve serbest eczacılarla hastaların iletişimini, eczacıların ilaç danışmanlığı ve 'İyi Eczacılık Uygulamaları' kapsamında farmasötik bakım verme niteliğini olumsuz etkilediği gösterilmiştir (30).

Araştırmaya katılan eczacıların devlet politikaları ve SGK yaptırımları nedeniyle karşılaştıkları en önemli 4 sorunu saptamak amacıyla uygulanan 5'li likert ölçek sonuçları Tablo 7'de görülmektedir.

Buna göre, araştırmaya katılan eczacıların büyük çoğunluğunun $(\% 95,4)$ sağlık, ilaç ve eczacılık politikalarının serbest eczacılığın seçeneklerini kısıtladığını ve olumsuz etkilediğini düşündüğü, sağlık politikaları ve geri ödeme uygulamalarının sık değişmesi nedeniyle işlerini yaparken zorlandıkları (\%84), SGK provizyon sisteminin çok sık kullanım dışı kaldığını $(\% 67,1)$ ve geri ödemeye ilişskin çok sayıda, zaman kaybına neden olan işlemle uğraştıkları $(\% 62,6)$ saptanmıştır (Tablo 7). Nitekim, araştırma bulgularımızı destekleyen bir başka çalışma 2003 yılında Ankara'da yapılan bir araştırmada ortaya çıımış ve eczacılık mesleğinin en önemli sorununun "problemli geri ödemeler" olduğu saptanmıştır (31). Türkiyedeki serbest eczacıların sorunlarının saptanması amacıyla yürütülen bir diğer çalışmada da, eczacılık hizmetleri esnasında en çok karşılaşılan sorunların sağlık politika ve uygulamaları ile geri ödeme kurallarının sık değişmesinden kaynaklandığı belirlenmiştir (32). 2005 yılında Edremit’te yürütülen bir başka çalışmada ise eczacıların büyük çoğunluğu anlaşmalı olduğu sağlık kurum ve kuruluşları ile olan ilişkilerinde ve geri ödeme uygulamalarında sorunlarla karşılaştığını belirtmiş, bu durumun serbest eczacılar için önemli stres kaynaklarından biri olduğu gözlenmiştir (33).

Araştırmaya katılan eczacıların tamamına yakını (\%97) ilaçtan elde ettikleri kazancın azalması sonucunda karı daha fazla olan ilaç dışı ürünlere yönelmelerinin dışsal faktörlerin serbest eczacılığa etki düzeyini arttırdığını düşünmektedir (Tablo 4). Serbest eczacılık uygulamalarına etki eden dişsal faktörlerin etki düzeylerini azaltılabilmesi için araştırmaya katılan eczacıların büyük çoğunluğu siyaset ve politikaların serbest eczane ekonomisi ve uygulamalarını destekleyecek şekilde düzenlenmesi gerektiğini düşündükleri $(\% 88,5)$ ve toplum sağlığına etkili ürünlerin satışının kontrol altında tutabilmesi için eczane dışı satışlarının önlenmesini ve bu ürünlerin sadece eczanede satılabilmesini sağlayacak düzenlemelerin gerçekleştirilmesini $(\% 87,8)$ ve tüketicilerin

Tablo 7. Devlet politikaları ve SGK yaptırımlarının serbest eczane uygulamalarına etkileri

\begin{tabular}{|c|c|c|c|c|c|c|}
\hline & 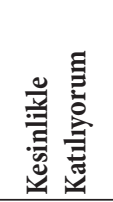 & 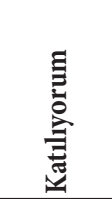 & 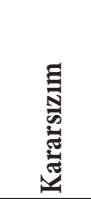 & 䏤 & 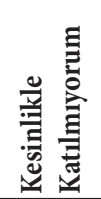 & : \\
\hline $\begin{array}{l}\text { Sağlık, ilaç ve eczacılık politikalarının serbest eczacıllı̆ın seçeneklerini } \\
\text { kısıtladığını ve olumsuz etkilediğini düşünüyorum }\end{array}$ & $\begin{array}{c}101 \\
(\% 77,1) \\
\end{array}$ & $\begin{array}{c}24 \\
(\% 18,3) \\
\end{array}$ & $\begin{array}{c}3 \\
(\% 2,3) \\
\end{array}$ & $\begin{array}{c}3 \\
(\% 2,3)\end{array}$ & - & - \\
\hline $\begin{array}{l}\text { Sağlık Politikalarının ve geri ödeme uygulamalarının sık değişmesi } \\
\text { nedeniyle ișimi yaparken sorunlarla karşılașıyorum }\end{array}$ & $\begin{array}{c}57 \\
(\% 43,5) \\
\end{array}$ & $\begin{array}{c}53 \\
(\% 40,5)\end{array}$ & $\begin{array}{c}3 \\
(\% 2,3) \\
\end{array}$ & $\begin{array}{c}17 \\
(\% 13)\end{array}$ & $\begin{array}{c}1 \\
(\% 0,8)\end{array}$ & - \\
\hline $\begin{array}{l}\text { Geri ödemeye ilişkin çok sayıda, zaman kaybına neden olan işlemle } \\
\text { uğrașıorum }\end{array}$ & $\begin{array}{c}32 \\
(\% 24,4)\end{array}$ & $\begin{array}{c}50 \\
(\% 38,2)\end{array}$ & $\begin{array}{c}5 \\
(\% 3,8) \\
\end{array}$ & $\begin{array}{c}36 \\
(\% 27,5) \\
\end{array}$ & $\begin{array}{c}8 \\
(\% 6,1)\end{array}$ & - \\
\hline SGK Provizyon Sistemi çok sık kullanım dışı kalıyor & $\begin{array}{c}21 \\
(\% 16)\end{array}$ & $\begin{array}{c}67 \\
(\% 51,1) \\
\end{array}$ & $\begin{array}{c}9 \\
(\% 6,9) \\
\end{array}$ & $\begin{array}{c}28 \\
(\% 21,4) \\
\end{array}$ & $\begin{array}{c}6 \\
(\% 4,6)\end{array}$ & - \\
\hline $\begin{array}{l}\text { Eczaneye destek (politikalar ve siyaset) ne yönden olursa olsun dişsal } \\
\text { faktörlerden etkilenme düzeyinin tüketicinin özelliğine göre (eğitim } \\
\text { düzeyi, gelir düzeyi) değișeceğini düșünüyorum. }\end{array}$ & $\begin{array}{c}46 \\
(\% 35,1)\end{array}$ & $\begin{array}{c}59 \\
(\% 45)\end{array}$ & $\begin{array}{c}1 \\
(\% 0,8)\end{array}$ & $\begin{array}{c}18 \\
(\% 13,7)\end{array}$ & $\begin{array}{c}6 \\
(\% 4,6)\end{array}$ & $\begin{array}{c}1 \\
(\% 0,8)\end{array}$ \\
\hline
\end{tabular}


bilinçlendirilerek $(\% 70,2)$ ilaç dışı ürünlerin reklamlarının eczaneler tarafindan da yapilabilmesini istedikleri $(\% 60,3)$ anlaşılmaktadır (Tablo 8).

Tablo 8. Dişsal faktörlerin eczane ekonomilerine etki düzeylerini azaltabilecek yöntemler hakkında eczacı görüşleri

\begin{tabular}{|l|c|c|}
\hline & $\mathbf{N}=\mathbf{4 4 2}$ & $\%$ \\
\hline Tüketiciler bilinçlendirilmeli & 92 & 70,2 \\
\hline $\begin{array}{l}\text { Serbest eczanede satılan ürünlerin sınırları } \\
\text { belirlenmeli ve sadece eczanede satılabilmeli }\end{array}$ & 115 & 87,8 \\
\hline $\begin{array}{l}\text { Serbest eczanelerde ilaç dışı ürünlerin reklamı } \\
\text { yapılabilmeli }\end{array}$ & 79 & 60,3 \\
\hline $\begin{array}{l}\text { Siyaset ve politikalar serbest eczane ekonomisi ve } \\
\text { uygulamalarını desteklemeli }\end{array}$ & 116 & 88,5 \\
\hline $\begin{array}{l}\text { Lisans eğitiminde branşlaşma gerçekleştirilmeli, } \\
\text { bu branşlardan serbest eczacıllğı seçenler eczane } \\
\text { açabilmeli }\end{array}$ & 39 & 29,8 \\
\hline Diğer & 1 & 0,8 \\
\hline
\end{tabular}

*Araştırmaya katılan 131 eczacı birden fazla yanıt vermiştir.

\section{Sonuç ve Öneriler}

$\mathrm{Bu}$ araştırmada, eczanelerin çoğunluğunun $(\% 82,4)$ en önemli ürün alıcısının SGK olduğu ve gelirlerini ağırlıklı olarak ilaç satışından $(\% 74,8)$ sağladıkları, eczane lokasyonları ile eczanede en çok satışı gerçekleştirilen ürün grupları arasındaki farkın istatistiksel olarak anlamlı olduğu ve hastane karşısındaki eczanelerde $(\% 89,7)$ en çok ilaç satışını gerçekleştiği belirlenmiştir. Ancak, eczacıların tamamına yakının (\%96,2), reçeteli ilaç satışlarına etki eden en önemli dışsal faktörün "devletin sağlık-ilaç politikaları" olduğu ve bu faktörün serbest eczane ekonomilerini olumsuz etkilediğini düşündükleri saptanmıştır.

Eczacıların büyük çoğunluğunun (\%95,4), sağlık, ilaç ve eczacilık politikalarının serbest eczacılı̆̆ın seçeneklerini kısıtladığını ve olumsuz etkilediğini düşündüğü, saptanmıştır. Bunun yanı sıra eczacıların \%84'ü geri ödeme uygulamalarının sık değişmesi, \%67,1'i SGK provizyon sistemindeki sorunlar $\% 62,6 \mathrm{i}$, zaman kaybına neden olan geri ödeme işlemleri nedeniyle işlerini yaparken sorun yaşadığını belirtmiştir.

Diğer taraftan ilaç fiyat kararnamesine bağl ilaç fiyatlarındaki düşüşler, kamu kurum ıskontosu, global bütçe gibi sağlık, ilaç ve eczacilık politikalarından kaynaklanan uygulamaların ilaçtan elde edilen kazancı azaltması sonucunda, eczacılar ilaç dışı ürün satışlarına yönelmiştir. Nitekim eczanelerin yaklaşık olarak yarısının, ilaç dışı ürün satışlarından elde ettikleri toplam payın, yıllık cirolarının \%20-50'sine ulaştığı, belirlenmiştir. Fakat, eczacıların neredeyse tamamı ilaçtan elde edilen kazancın azalması sonucu ilaç dışı ürünlere yönelmenin dışsal faktörlerin serbest eczacılığa etki düzeylerini arttırdığını düşünmektedir. Ayrıca, eczacıların benzer ürün satışı yapan "aktarlar, dermakozmetik satıcları, marketler, internet üzerinden satış yapanların, medya araçları, reklamlar, Tv programlarıyla tüketicilerin algısına etki ederek eczanede satılan benzer ürünlerin pahalı olduğu imajı yaratıldığı, toplumu yanlış yönlendirdiklerini, bu dışsal faktörlerin etkisiyle, benzer ürün satıcılarının eczaneler aleyhine haksız rekabet yarattıkları ve serbest eczane ekonomilerine olumsuz etki ettiklerini düşündükleri saptanmıştır.

Serbest eczacilık uygulamalarına etki eden dışsal faktörlerin etki düzeylerinin azaltılabilmesi için araştırmaya katılan eczacıların büyük çoğunluğunun (\%88,5) devletin sağlık-ilaç politikalarının serbest eczane ekonomisi ve uygulamalarını destekleyecek şekilde düzenlenmesi gerektiğini ve toplum sağlığına etkili ürünlerin satışının kontrol altında tutabilmesi için eczane dışı satışlarının önlenmesini ve bu ürünlerin sadece eczanede satılabilmesini sağlayacak düzenlemelerin gerçekleştirilmesini $(\% 87,8)$ ve tüketicilerin bilinçlendirilerek $(\% 70,2)$ ilaç dışı ürünlerin tanıtımlarının eczaneler tarafından yapılabilmesini $(\% 60,3)$ sağlayacak düzenlemelerin yapılması gerektiğini düşündükleri saptanmıştır.

2004 yılında yürürlüğe giren "ilaç fiyat kararnamesi” (referans fiyat) ile son on yılda ilaç fiyatlarında $648 \mathrm{kez}$ indirim yapılmış ve eczanelerde önemli stok zararları oluşmuştur. 2005 Mali Yılı Bütçe Uygulama Talimatı ile yürürlüğe giren ve her yıl arttırılan "Kamu Kurum Iskontosu" ile 2009 yılında yürürlüğe giren ve kamu ilaç harcamalarını belirli bir limitle sınırlandıran "Global Bütçe" uygulamalarıly eczanelerin ilaç gelirleri önemli ölçüde azalmıştır. Buna karşın eczane işletme giderleri (kira, personel maaşları gibi) ise her yıl artan enflasyona bağlı olarak giderek arttı̆ğından, eczanelerin reel gelirlerinde büyük kayıplar olmuştur.

Gerek toplum sağlığının korunması ve yükseltilmesi, gerekse eczane ekonomilerinin düzeltilebilmesi için;

- Eczacılara danışmanlık hizmetleri için meslek hakkı ödenmesi,

- İlaç endüstrisi tarafından kaldırılan ticari iskontoların yeniden uygulanmass,

- SGK protokolündeki eczacı indirimlerinin sıfırlanması

- Kamu Kurumu Iskontolarının eczanelerden değil, SGK tarafından doğrudan kaynağından (İlaç sanayii) tahsil edilmesine yönelik düzenleme yapılması,

- Muayene ücretlerinin hastanelerden tahsil edilmesi,

- İnternet üzerinden sağlı ürünleri satışının engellenmesi,

- Gıda takviyeleri ve bitkisel ürünlerin Sağlık Bakanlığından ruhsatlandırılması ve sadece eczanelerde satılabilir ürünler kapsamına alınmasının ivedilikle yapılması gereken düzenlemeler olduğu düşünülmektedir. 
Opinions of Pharmacists' on Effect Levels of External Factors on Community Pharmacy Economies

\section{Abtract}

Recently, new regulations were implemented to comply with health policies of European Union and World Health Organization, and to reduce health care cost in our country. These regulations were affected negatively pharmacy economies. Pharmacists had to struggle with numerous external factors to sustain their businesses.

This study was conducted by face-to-face survey of 30 questions to 131 volunteer pharmacies in Izmir to identify pharmacists' opinions about effect levels of external factors on community pharmacy economies such as similar product sellers, media, consumer features, Social Security Institution and government policies. Data were evaluated by frequency, percentage distribution and chi-square test using SPSS18 Package Program. According to pharmacists, the most important buyer is Social Security Institution(82.4\%) and the most important external factor affecting sale of prescription drugs is health and drug policies(96.2\%). However, nearly all pharmacists(97\%) think that there is an increase for non-pharmaceutical products in the last few years due to decreased gain from drugs. Thus, it was increased the level of being affected of pharmacy economies by external factors. Advertisements(38.9\%) and consumer features(33.6\%) were identified as major external factors that affect sale of over-the-counter products.

It was identified that $88.5 \%$ of pharmacists think that it is necessary to make regulations to support community pharmacy economies in health-drug policies by government for contribution of pharmacists to community health by reducing these external factors. Therefore, practices such as selling effective products for community health only at pharmacies and awareness of consumers, etc. should be implemented immediately.

Keywords: Pharmacy, Community Pharmacy, Pharmacy Administration, Economics

\section{Kaynaklar:}

1. Keyder Ç, Üstündağ N, Ağartan T, Yoltar Ç. Avrupa'da ve Türkiye’de Sağlık Politikaları. İletişim Yayınevi, İstanbul, Türkiye. 2007, pp 7-13.

2. Yalçın Balçık P, Karsavuran S. Dünya'da ve Türkiye’de İlaç Fiyatlandırması. Hacettepe Sağlık İdaresi Derg 2012; 15: 3867.

3. 14.02.2004 tarih ve 25373 sayılı Resmi Gazete'de yayımlanan Beşeri Tibbi Ürünlerin Fiyatlandırılmasına Dair Karar http://www.resmigazete.gov.tr/main.aspx?home=http:// www.resmigazete.gov.tr/eskiler/2004/02/20040214. ht m \& m a in =http:// www.resmigazete.gov.tr/ eskiler/2004/02/20040214.htm [Erişim Tarihi: 16.02.2016].

4. 09.02.2005 tarih 25722 sayılı Resmi Gazetede yayımlanan 2005 Mali Yılı Bütçe Uygulama Talimatı http://www. resmigazete.gov.tr/main.aspx?home=http://www.resmigazete. gov.tr/eskiler/2005/02/20050209m1.htm\&main=http:// www.resmigazete.gov.tr/eskiler/2005/02/20050209m1.htm [Erişim Tarihi: 16.02.2016].

5. Usta S. Eczane Ekonomilerine Güncel Bakış. 13.Türkiye Eczacılık Kongresi, Bildiri Özeti, s.24-25.

6. Akyürek EÇ. Sağlıkta bir geri ödeme yöntemi olarak global bütçe ve Türkiye. Sosyal Güvenlik Derg 2012;2:124-53.

7. Bayraç ZB. Yüksek Lisans Tezi. Türkiye'de İlaç Pazarının Gelişimi Ve Karaman İli Örneği. T.C. Karamanoğlu Mehmetbey Üniversitesi Sosyal Bilimler Enstitüsü İşletme Ana Bilim Dalı, Karaman, Türkiye. 2011, pp.109.

8. Türkiye İstatistik Kurumu İstatistiksel Tablolar ve Dinamik Sorgulama, 2007-2016 Aralık Ayları Tüketici Fiyatları Endeksi http://www.tuik.gov.tr/PreTablo.do?alt_id=1014

[Erişim Tarihi: 20.02.2017].

9. Kıran B. Dışsal faktörlerin serbest eczacılıkta yarattı̆̆ 1 haksız rekabet ve halk sağlı̆̆ına etkileri. Denge Derg 2015;43:20-1.
10. Tı̆̆ EÖ, Ayanoğlu Dülger G, Hıdıroğlu S, Toklu HZ. serbest eczacıların elektronik bilgi kaynağı kullanımı. Marmara Pharm J 2012;16:29-35.

11. Demircan D, Çanga B, Gün M, Ünal Ç, Önem İ, Akıcı A. Üniversite öğrencilerinin ilaç/tıbbi ürün kullanımına yönelik tutumlarının değerlendirmesi. Marmara Med J 2010;23: 27684.

12. Yılmaz M, Güler N, Güler G, Kocataş S. Bir grup kadının ilaç kullanımı ile ilgili bazı davranışları: Akılcı Mı? Cumhuriyet Med J 2011; 33: 266-77.

13. Zerenler M. Konya ilinde faaliyet gösteren eczanelerin algılanan hizmet kalitesi, hasta beklentileri ve sorunların belirlenmesine yönelik araştırma. 5.Bölge Konya Eczacı Odası Yayın1, Konya. 2015, pp 14-46.

14. Düşük Cirolu Serbest Eczaneler Araștırması 2007, Türk Eczacıları Birliği Araştırma Dizisi(http://www.e-kutuphane. teb.org.tr/pdf/raporlar/dusuk_cirolu/10.pdf) [Erişim Tarihi: 20.04.2016]

15. Čábyová L, Krajčovič P, Fedorová $\mathrm{M}$. The effect of media channels on sales of over-the-counter drugs and food supplements. EJST 2015;11:239-49.

16. Penpece D. Yüksek Lisans Tezi. Tüketici Davranışlarını Belirleyen Etmenler: Kültürün Tüketici Davranışları Üzerindeki Etkisi. T.C. Kahramanmaraş Sütçü İmam Üniversitesi, İşletme Anabilim Dalı, Kahramanmaraş, Türkiye. 2006.

17. Akagün Ergin E, Özdemir Akbay H. Giyim ve gıda ürünleri kategorilerinde tüketicilerin plansız satın alma davranışları üzerine bir araştırma. Afyon Kocatepe Üniversitesi İİBF Derg 2011;8:275-92.

18. Okutan S, Bora B, Altunışık R. Keşifsel satın alma eğilimleri ve bu eğilimlerin plansız, kompülsif ve hedonik satın alma tarzlarıyla olan ilişkisinin incelenmesi. Eskişehir Osmangazi Üniversitesi İIBB Derg 2013;8:117-36. 
19. Çelenk F. Çeșitli Mal ve Hizmetlerle İlgili Reklam Yasaklama ve Sinırlamalar1 http://www.tuketici.gov.tr/source.cms. docs/etuketici.gov.tr.ce/docs/yayinlar/FATIH_CELENK.pdf [Erişim Tarihi: 25.04.2016].

20. Gülpınar G, Özçelikay G. OTC Drug regulations in Turkey: The opinions of community pharmacists and drug industry. Turk J Pharm Sci 2015; 12: 267-78.

21. Potnis PS. MSc Thesis. Ohio Pharmacists' Perceptions Of Over-The-Counter Drug Advertising. The University of Toledo in Pharmaceutical Science, Toledo. 2012.

22. Şencan N, Uyar M. Hasta hakları bağlamında direkt tüketiciye ilaç reklamları üzerine kalitatif bir çalışma. Marmara Pharm J 2014;18:164-76.

23. Cömert Y, Durmaz Y. Tüketicinin tatmini ile satın alma davranışlarını etkileyen faktörlere bütünleşik yaklaşım ve Adıyaman ilinde bir alan çalışması. J Yaşar Univ 2006; 1: 35175.

24. Tüketici Davranış Modelleri. T.C. Milli Eğitim Bakanlığı Aile ve Tüketici Hizmetleri Yayını. Ankara. 2012, pp.17.

25. 12.04.2014 tarih ve 28970 sayılı Resmi Gazete'de yayımlanan Eczacılar ve Eczaneler Hakkında Yönetmelik, İyi Eczacılık Uygulamaları Kılavuzu, http://www.titck.gov.tr/PortalAdmin/ Uploads/UnitPageAttachment/b607e1a453003.pdf [Erişim Tarihi: 28.04.2016].

26. Özdemir B. Geleceğin Eczanesini Tasarlamak. Elma Yayınevi, Ankara, Türkiye. 2012, p.133.
27. 12.04.2014 tarih ve 28970 sayılı Resmi Gazete'de yayımlanan Eczacılar ve Eczaneler Hakkında Yönetmelik http://www. resmigazete.gov.tr/eskiler/2014/04/20140412-14.htm [Erişim Tarihi: 03.05.2016].

28. Blacksell L, Byard RW. Forensic problems with the composition and content of herbal medicines. J Forensic Leg Med 2014; 23:19-21.

29. Kaynak: Türk Eczacıları Birliği 03.03.2016 tarihli basın açıklaması, İnternetten Temin Edilen İlaçların Hemen Hemen Hepsi Sahte [Erişim Tarihi: 10.05.2016]. olarak düzeltilecek..

30. Kıran B. Serbest Eczacıların Sosyal Güvenlik Kurumu ile yaptıkları protokollerden kaynaklanan sorunlar. Turkiye Klinikleri J Med Ethics Law Hist-Special Topics 2015;1:23-31

31. Altıntaş KH, Çakır B, Temel F. Ankara 9. bölge eczanelerinde çalışan eczacıların bazı mesleki uygulamalarını ve sorunlarını saptama araştırması. Ankara Ecz Fak Derg 2004; 33: 11-25.

32. Kocabacak S. Türkiye'de serbest eczanelerin sorunlarına yönelik bir araştırma. Hacettepe Sağlık İdaresi Derg 2011;14:95-124.

33. Ercan AA, Şar S. Edremit Körfez bölgesindeki eczane eczacılarının stres kaynakları. Ankara Ecz Fak Derg 2004;33: 217-42. 